International Journal of Business and Management 2 (6): 36-42, 2018

e-ISSN: 2590-3721

(C) RMP Publications, 2018

DOI: $10.26666 / \mathrm{rmp} . \mathrm{ijbm} .2018 .6 .6$

\title{
Integrating Cash Waqf : Collaboration Between Bank Muamalat Malaysia Berhad (BMMB) and Perbadanan Waqf Selangor (PWS)
}

\author{
Zainora Bt Hayari, Nur Riana Bt Abd Rahim and Multazimah Bt Md Daud \\ Commerce Department, Premier Ungku Omar Polytechnic, \\ Jalan Raja Musa Mahadi, 31400 Ipoh, Perak, Malaysia.
}

\begin{abstract}
This paper discusses the collaboration between Bank Muamalat Malaysia Berhad (BMMB) and Perbadanan Waqf Selangor (PWS) in integrating cash waqf management for the maslahah especially Muslim in Malaysia. It also examines how these two organizations jointly collaborate for the purpose of managing Cash Waqf relating the roles, objectives, issues and challenges and the sustainability of jointly management committee between BMMB and PWS. This successful effort gives a chance to public who do not have any assets or properties to make cash contribution in waqf. The respondents of the study comprised executive and management level from each organization and institution. The research focuses on the future planning and sustainability of BMMB and PWS in ensuring the continuous increment of the cash waqf fund. This research was based on qualitative method and the data was collected directly from the key person in each organization and institution. The implication from this study shows that, there is a need for an effort and plan to ensure the sustainable success of BMMB and PWS in managing the cash waqf. The study proposes that either BMMB or PWS and also industry player should make a continuous promotion to enhance the public knowledge to always sustain and increase the awareness of Cash Waqf.
\end{abstract}

Keywords: Cash Waqf, cash waqf management, continuous increment, sustainability

\section{INTRODUCTION}

Waqf or endowment is one of the charities that are highly demanded in Islam. It is a running charity of continuous benefit rewarded from Allah S.W.T. for any dedication of ones's possessions donated for charitable purposes. The word - Waqf comes from the Arabic, which means stop or hold, contain or preserve. This means, assets that are donated, grant, create and bequeathed for a pious or charitable purpose and seeking rewards from Allah S.W.T.. There are many verses in Al-Quran that encourage Muslims to do good deeds like charity deeds, grants, donations and many more. In addition, there are also some hadith the Prophet which demanded Muslims do practice this virtue.

Hadith Narrated by Muslim; "When the son of Adam dies, will cease the deeds except for three things: charity deeds (wakaf or property endowed), which appropriates knowledge and a good son (soleh)".

From the previous decades until now, waqf is always needed in Islam although it is not compulsory. Especially when we talk about how to handle poverty alleviation, Waqf is always associated with this issue in Muslim countries. It is proven in Malaysia, where there is an increasing number in total waqf land by the Muslims from time to time. Historically, the institution of waqf had achieved its peak during the Ottoman Sultanate in terms of numbers, assets and the services it was rendering to the citizens ranging from municipal services to education, health, culture and Religion. During this time, cash waqf had also served the role financier, granting loans to people in need of them [1]. The returns obtained by the cash waqf were in turn channeled to the public purposes determined by the founder ranging from education to food support for the

Corresponding Author: Zainora Bt Hayari, Commerce Department, Premier Ungku Omar Polytechnic, Jalan Raja Musa Mahadi, 31400 Ipoh, Perak, Malaysia, zainora79@gmail.com 
poor [2]. Normally waqf usually focused on the land or building, but not many people or the donors have the asset to do waqf and therefore, cash waqf has become as a great alternative for individual who just have movable assets such as cash for donating. Thus, everyone can do a charity in form of cash waqf as long as they want to do it voluntary only for the sake of Allah S.W.T blessing. Jabatan Wakaf, Zakat and Hajj (JAWHAR) website reported that the total amount of Waqf land in Malaysia is $8,825.03$ hectares which is equivalent to almost RM 63,729,853.50 [3]. It shows that the awareness and trust among Muslim was rapidly increased. However, practicable and applicable mechanisms need to be strengthened towards increasing the cash waqf collection. Thus, the initiative taken by Bank Muamalat Malaysia (BMMB) Bhd. to collaborate with Perbadanan Wakaf Selangor (PWS), enabling both parties to jointly managed waqf service fund in order to enhance the collection of cash waqf. The aim of this study is to highlight the role of Bank Muamalat Malaysia Berhad (BMMB) and Perbadanan Waqf Selangor (PWS) in sustaining their collaboration as Waqaf Selangor-Muamalat. This study may prevail the issues and challenges of BMMB in collaborating with PWS related to cash waqf management. It described the action taken by BMMB in order to sustain the cash waqf fund and collaboration with PWS. It also examined the opportunities and benchmark for this two parties to be successful in managing the cash waqf fund in Malaysia. On top of that, this study can increase the responsiveness among Muslims to better know about this collaboration in cash waqf management and will be more conscious on cash waqf. It analysed Wakaf Selangor Muamalat from several main aspects such as their roles, objectives, issues and challenges, future planning and the sustainability between these two parties.

\section{Research objective}

The aim of this study is to highlight the role of Bank Muamalat Malaysia Berhad (BMMB) and Perbadanan Waqf Selangor (PWS) in sustaining their collaboration as Waqaf Selangor-Muamalat.

The objectives of this study are to:

1. To explain the roles and objectives of introducing Cash Waqf and collaboration between BMMB and PWS.
2. To identify the issues and challenges related to Cash Waqf Management in BMMB.

3. To deliberate on the sustainability consideration of Waqaf Selangor Muamalat

\section{Research Question}

In fulfilling the objectives of this research, the following research questions were developed. The research questions formulated to guide this study are as follows:

1. What is the Bank Muamalat role in introducing cash waqf in Malaysia?

2. What is the main objective for Bank Muamalat in making collaboration with Perbadanan Waqaf Selangor (PWS)?

3. What are the main issues or challenges related to cash waqf management in BMMB?

4. What are the steps or efforts that will be taken or already being taken in order to sustain the cash waqf fund?

5. What are the steps or efforts that will be taken or already being taken in order to sustain the collaboration between BMMB and PWS?

6. What is your future planning to become more successful in collaborate with PWS?

7. What are the opportunities that have been identified in expanding the benefits of cash waqf?

8. What is Bank Muamalat's benchmark in managing the cash waqf fund?

\section{LITERATURE REVIEW}

A study by Dr.Abul Hassan and Mr.Mohammad Abdus Shahid [4] stated that Waqf is a form of continuous charity (sadaqah jariah).

The rewards for this type of charity continue even after the donor's death for as long as people continue to benefit from the waqf. Magda (2009) stated that the waqf will receive cash instead of property or land and will use it for the financing instead of relying on banks or financial institutions. Cash waqf is created in the form of movable waqf (money) to establish liquid money in order to finance services and develop waqf property or to support and build an educational institution (schools or universities) or orphanage houses in the name of Allah S.W.T. The waqf property is prohibited from being used or disposed of outside of the specific purpose for which it is held. 
Most research show there are no legal references on specific verses in the Al-Quran that mentioning waqf in specific. Muslims are relying on the Sunnah of Prophet Muhammad (pbuh) and the actions of his companions in practicing waqf. However, there is a verse on charity which carries the practicing of waqf in the following Quran verse:

"Never will you attain the good (reward) until you spend (in the way of Allah) from that which you love. And whatever you spend - indeed, Allah is knowing of it" (Surah Al-'Imran, 3:92)

Succeeding the earlier definition on waqf which hold the concept of charity with the intention of prohibiting any use of disposition of the property outside the specific purposes to which the property is dedicated, in such a way it cannot be inherited or sold. Rininta [6] in her paper define cash waqf as an amount of money/cash of the founder that to be utilized to fund project which beneficial for the society. The endowed cash used to be invested or loaned out to earn income, and target projects were financed by earned income. The creation of cash waqf is been approved by the four school of thought and must obey the three restrictions of cash waqf, consists of; (1) Irrevocability - founder cannot revoke the sum of waqf money that has already declared as waqf; (2) Perpetually - once the money has been waqf, the mutawalli must ensure the regular and continue support of the beneficiaries; and (3) Inalienability - once cash waqf is created, it cannot be transferable, in any forms of gift, inheritance or any alienation.

Nowadays, most Muslim countries recognized the potential of reforming the management of cash waqf. They fulfilled their social responsibilities and served their societies through the institution of waqf which is non-profit institution without any cost to government [5]. The basic of waqf itself is to serve the welfare of society at large and provide necessity for sustainable public utilities. According to Mannan [7], contribution of cash waqf to socio-economic developing countries is significant. Fund collected trough cash waqf certificate program was allocated into several area including agricultural, education, health and infrastructure. Mostly the mobilization of this fund for poverty alleviation programs and other public service development.

\section{Organizations of Study}

\section{Bank Muamalat Malaysia Berhad}

Bank Muamalat is one of the two independents fullfledged Islamic financial institutions. The Bank was established on 1 October 1999 from the Islamic banking divisions of the former Bank Bumiputra Malaysia, Bank of Commerce (Malaysia) and BBMB Kewangan. The shareholders comprise DRB-HICOM, with 70\% shares in the bank while Khazanah Nasional owns the remaining.

Being among the pioneer of Islamic banking, the Bank is strongly supported by Shariah's scholars who are highly qualified and experienced in the Islamic jurisprudence, advising not only in issues pertaining Shariah products and services but also as advisors to parties that are planning to raise Islamic Capital Issues or other new innovative products. It provides wide range of Islamic banking products and services including foreign currency deposits, investment accounts, foreign exchange trading, working capital financing, trade financing, project and contract financing, venture capital and Islamic capital market services to both Malaysians and foreigners. Bank Muamalat Malaysia is one of two independents and domestically owned Islamic banks in Malaysia.

\section{Selangor Endowment Corporation (Perbadanan Wakaf Selangor)}

On 30th October 2009, His Royal Highness (HRH) Sultan of Selangor has commanded the establishment of Perbadanan Wakaf Selangor (Selangor Endowment Corporation) under Selangor Islamic Religious Council (MAIS). Perbadanan Wakaf Selangor (PWS) has been incorporated on 1st July 2011 according to HRH Sultan's decree. PWS manages the waqf fund under the Waqf Enactment (Selangor State) No.7, 1999 and Selangor Waqf Corporation Order 2011 and according to Islamic Religious Administration Enactment (Selangor State 2003) (amendment 2008) [8], to achieve its main objective to enhance added value in waqf property management and nurture the waqf practices towards an efficient and holistic muslims economic development, according to shari'ah rules. 
PWS is one of the pro active waqf fund management body in Malaysia that is responsible to give advice to MAIS regarding policies, methods and steps that have to be executed to encourage waqf property and products development. This corporation also involve in planning and organizing the development of waqf property and products, managing and maintaining waqf properties including amenities and infrastructures on the waqf property, acting as the coordinator in waqf property and products management and also encourage and coordinating the research and development in every aspects of waqf property and products.

Other than the ordinary immovable waqf property, PWS is managing several cash waqf products like Saham Wakaf Selangor (Selangor Waqf Shares), Skim Infaq (Infaq Scheme) and Sahabat Korporat (Corporate Partners). Saham Wakaf Selangor is a way of cash waqf that involves acquiring of shares that are offered by MAIS (the waqf trustee of Selangor state), in order to give the shares as waqf for the benefits of the ummah. Therefore, capital to develop and buying waqf property like land and real estate can be gained through the sales of waqf shares. In addition, this product is hoped to create awareness among muslims to encourage them to involve in waqf as it can be seen as a potential system to enhance socioeconomic development. Other than that, PWS also facilitate

muslims to donate to the waqf fund through monthly salary deduction under Skim Infaq, and also build a partnership through Sahabat Korporat with several private companies and Government linked company (GLC), in order to increase the waqf fund. Other than that, PWS has also launched a new and innovative product called Wakaf Seni in 2013, in order to get more people involves in waqf.

This has been done through the involvement of people from the entertainment industry who would like to donate a part of their payment from the entertainment industry to the waqf fund. Among the target people from the industry are song writers, film producers and celebrities.

In year 2006 to 2012, PWS has managed to distribute more than RM 200,000 of the waqf fund mostly to the development and upgrading of Islamic religious places, like surau and mosque. The waqf fund also goes to the development of waqf clinics, maintainance of muslims cemetery and the books waqf programme. PWS also distributes the waqf benefits (manfaat wakaf) that have been received from the rental fees of the Bazar Rakyat (Community Shop) and rented waqf land to the partnered mosques. PWS shows excellent achievements throughout its establishment that makes it one of the benchmark to the other waqf fund management bodies throughout this country.

\section{Selangor State Islamic Religious Council (Majlis Agama Islam Selangor)}

In Selangor, previously, the State of Islamic Religious Council named Majlis Agama Islam dan Adat Istiadat Melayu Selangor was established under Section 5, Pentadbiran Undang-undang Islam 1952 Enakmen No. 3 Tahun 1952. The primary objective was to assist and advise the Duli Yang Maha Mulia Sultan Selangor in Islamic and cultural matters. In 2004, its name and identity changed to a statutory body and was renamed as Majlis Agama Islam Selangor (MAIS) under Section 5(1), Enakmen Pentadbiran Agama Islam (Negeri Selangor) 2003.

In March 2005, the Department of Baitulmal Management, Jabatan Agama Islam Selangor (JAIS) was separated and transferred to MAIS and approved by MAIS in a meeting on 14 April 2005. The separation was to fulfill the requirement of Seksyen 81(3) Enakmen Pentadbiran Agama Islam (Negeri Selangor) 2003 [8] which stated that MAIS had the power to manage and was accountable for all assets included Waqf. The function of MAIS was to encourage, assist and manage in ensuring a successful economic social success of the Muslims in Selangor parallel with the syara'.

\section{METHODOLOGY}

According to Bryman [9] and Sekaran [10], an interview may be performed by face-to-face meetings, telephone conversations, email or another computer-assisted means. Qualitative method was used in the form of semi-structured interview as the method in collecting data about the roles, functions and sustainability of the Waqf Selangor Muamalat in managing the cash waqf. The data gathered from the interview sessions were used to explain their opinions.. The questions ask in the interview are listed as follows: 
Interview Question 1: What is the Bank Muamalat role in introducing cash waqf in Malaysia? This question is consistent with the research objective which aims to obtain a clear insight into the roles of BMMB and PWS.

Interview Question 2: What is the main objective for Bank Muamalat in making collaboration with Perbadanan Waqaf Selangor (PWS)?

Interview Question 3: What are the main issues or challenges related to cash waqf management in BMMB?

These questions are formulated in line with the research objectives which aim to identify the issues and challenges related to Cash Waqf Management in BMMB.

Interview Question 4: What are the steps or efforts that will be taken or already being taken in order to sustain the cash waqf fund?

Interview Question 5: What are the steps or efforts that will be taken or already being taken in order to sustain the collaboration between BMMB and PWS?

Interview Question 6: What is your future planning to become more successful in collaborates with PWS?

Interview Question 7: What are the opportunities that have been identified in expanding the benefits of cash waqaf?

Interview Question 8: What is Bank Muamalates benchmark in managing the cash waqf fund?

The above mentioned set of questions seeks to inquire and deliberate on the sustainability consideration of Waqaf Selangor Muamalat\| by BMMB and PWS in successful managing the cash waqf.

\section{DATA ANALYSIS AND FINDINGS}

\section{Interviewees' Profiles}

The total number of respondents for this study was three (from the three leading companies), including from the top management level and executive level in the company. A series of three interviews were carried out with those who are involved directly in the management. The researcher was able to get respondents from the management level at Bank Muamalat Malaysia Berhad, Perbadanan Waqf Selangor and Yayasan Waqf Malaysia would only allow their executive level to correspond with the researcher. The independent observations and views that result from individual interviews give a special quality to the data obtained for this study.

\section{Analysis}

1. Bank Muamalat Malaysia Berhad (BMMB): Role in Introducing Cash Waqf in Malaysia.

Firstly is to jointly manage waqf fund with good governance and transparencies in giving confidence and motivation to public as a whole. Secondly is to extend its infrastructure (example branch network) and its expertise in banking (example investment) to collect waqf fund and to expand the value of waqf through investment activities.

\section{BMMB's Objectives in Making Collaboration with} Perbadanan Waqf Selangor (PWS).

As for BMMB's and PWS, the main objective in making collaboration is to be the authorized entity by a Majlis Agama Islam Negeri (MAIN) to collect and manage waqf fund together with PWS.

\section{The Main Issues or Challenges Related to Cash Waqf Management in BMMB.}

Firstly is to process the waqf application according to the criteria set by the Joint Management Committee (JMC). The criteria were set to ensure that only

applications that are really entitle for waqf are going to be approved. Secondly is the process of monitoring waqf assets to ensure that the assets are in good care. Finally is on public awareness on cash waqf and public confidence towards the institutions that are managing the waqf fund.

4. The Partnership Programmes That Have Been Done With Higher Education Institutions in Managing Cash Waqf.

As for this time being, BMMB are managing of cash waqf through the respective MAIN only, and for the higher education institutions it is still in the early stage. They really look forward to have more collaboration 
with higher education institutions. Thus it could be a new dimension of good governance in waqf affairs.

\section{Steps or Effort That Will Be Taken or Already Being Taken in Order to Sustain the Cash Waqf Fund.}

i. More advertisement and promotion activities - such as main radio stations and newspapers, media report on cash waqf to instill public confident and motivation and participate in live talks on radio station and conduct forum.

ii. To promote direct debit from customer's account Bank.

6. Future Planning To Be More Successful In Collaboration With PWS.

As for the successful collaboration in future, they want to collect more waqf fund and to implement more high impact waqf projects to the societies.

7. The Opportunities That Have Been Identified in Expanding the Benefits of Cash Waqf.

Firstly, they want to invest wakaf fund to expand the wakaf fund size through revenues gained. As a start, WSM to focus on acquiring property that can provide good rental or return. Secondly, the possibility of extend the same cash wakaf model to the other MAIN. Thirdly, they want to have more collaboration with other entities which are willing to collaborate in WSM projects for eg. Hospitals, NGO and others. Fourthly, once wakaf fund size is big, WSM can also explore in property development to generate more revenue to WSM. Last but not least sponsoring scholarship, medical fee and many more.

\section{BMMB's Benchmark in Managing The Cash Waqf} Fund.

There has no specific benchmark at this stage as WSM is gearing to implement more wakaf projects to induce more wakaf contribution and ensuring that the waqf contribution is in good hand.

\section{DISCUSSION}

The analysis provides a better understanding in the important of good governance and having strong collaboration in managing waqf fund. It could give confidence to the public in contributing cash wafq.

A special talk can be conducted by BMMB and PWS to every government agencies and private bodies in order to promote and give some awareness on cash waqf. In this forum they can encourage participants to contribute in cash waqf either by giving cash or directly debited from their salary's account. It could increase the total number of cash waqf. BMMB should have strong relationship with all MAIN. This effort will enhance the promotion of cash waqf to all Muslim. This effort also can encourage all non Muslim to contribute in cash waqf. Finally, in order to sustain in market, BMMB and PWS should always updating the successful projects or activities through utilizing the fund in cash waqf fund through media social and electronic. It can attract many people to contribute in cash waqf.

\section{CONCLUSION}

In conclusion, the property which can contribute to Waqf is not limited to only immovable property but it also can be a movable property such as cash. Collaboration between waqf agencies and islamic financial institutions indirectly encourage the community to practice charity deeds required in Islam. This seems to be more important in attracting people to be involved in waqf contribution. Finally, may all these efforts will directly influence the socio-economic well being of the Malaysian society resulting from the utilisation of the funds collected under Waqf agencies.

\section{REFERENCES}

[1] Cizakca, M. A (2000). History of Philanthropic Foundations: The Islamic World From the Seventh Century to the Present (Istanbul: Bogazici University Press, 2000).

[2] Cizakca, M. A (2004). Incorporated cash waqfs And mudaraba, Islamic non-bank financial Instruments from the past to the future, Bahcesehir University, Istanbul, Turkey. Retrieved from http://mpra.ub.uni-muenchen.de/25336/

[3] JAWHAR. (June 13, 2012). Portal i- Wakaf. Retrieved from http://www.jawhar.gov.my/iwakaf/

[4] Abul Hassan \& Mohammad Abdus Shahid (2010). Management and development of the Awqaf Assets. 
[5] Abdel Mohsin, Magda (2009). Cash Waqf a new financial product, Petaling Jaya, Prentice Hall.

[6] Rininta Nurrachmi, (2012). The implication of Cash Waqf in the society.

[7] Mannan, M.A.Abdul (1998). Cash Waqf, Enrichment of Family Heritage Generation to Generation, Social Investment Bank. Publication Series, no. 1, 1st edition, 1998.

[8] Enactment No.1 of 2003, Administration Of The Religion Of Islam (State Of Selangor) Enactment (2003). Part VI. Finance, Wakaf, Nazr And Trusts
Retrieved from

http://www2.esyariah.gov.my/esyariah/mal/

[9] Alan Bryman (2008), Of methods and methodology, Qualitative Research in Organizations and Management: An International Journal, Vol. 3 Issue: 2, pp.159 168 , Retrieved from https://doi.org/10.1108/17465640810900568

[10] Sekaran, U. (2003) Research Methods for Business: A Skill-Building Approach. 4th Edition, John Wiley \& Sons, New York. 